Jurnal Dinamika Sosial Ekonomi Vol.20 No.1, Juni 2019 : 39-54

ISSN 1411-593X (print)

\title{
ANALISIS PERSEDIAAN BAHAN BAKU MADU DENGAN PENDEKATAN ECONOMIC ORDER QUANTITY (EOQ) PADA PT. AKSAMALA ADI ANDANA
}

\section{The Raw Material Inventory Analysis of Honey with Economic Order Quantity Method in PT. Aksamala Adi Andana}

\author{
Ayu Fitriani Putri, Agus Santosa*, Ni Made Suyastiri YP \\ Program Studi Agribisnis, Fakultas Pertanian, Universitas Pembangunan Nasional \\ "Veteran" Yogyakarta \\ Jl. Padjajaran (Lingkar Utara 104) Condongcatur, Yogyakarta, Indonesia \\ email korespondensi : agussantosa1108@yahoo.com
}

Diterima tanggal : 3 Februari 2019 ; Disetujui tanggal : 30 April 2019

\begin{abstract}
This study aims to analyze honey raw material optimal orders, analyze the effect of ordering costs, storage costs, amount of usage and lead time on honey raw material inventories, analyze the trend of honey raw material needs from July to December 2018, analyze the safety stock of honey raw materials, analyze the reorder point of honey raw material. This research used descriptive method with the method of implementation was case study. The method of data analysis are EOQ model (Economic Order Quantity) analysis, multiple linear regression analysis, trend analysis, safety stock analysis and reorder point analysis. The results showed that the optimal ordering of honey raw materials was 6,524 $\mathrm{kg} / \mathrm{order}$ with a frequency of 17 orders. The storage cost factor and the amount of usage affect the raw material inventory while the ordering cost and lead time factors do not affect the raw material inventory at PT. Aksamala Adi Andana. Trend of honey raw material needs at PT. Aksamala Adi Andana in July to December 2018 tends to increase. Safety stock of honey raw materials that must be available at PT. Aksamala Adi Andana that is equal to $766 \mathrm{~kg}$. Reorder point for honey raw material at PT. Aksamala Adi Andana was $2.915 \mathrm{~kg}$.
\end{abstract}

Keywords: economic order quantity, honey, safety stock, raw material inventory, reorder point

\begin{abstract}
ABSTRAK
Penelitian ini bertujuan untuk menganalisis pemesanan bahan baku madu optimal, menganalisis pengaruh biaya pemesanan, biaya penyimpanan, jumlah pemakaian dan waktu tunggu terhadap persediaan bahan baku madu, menganalisis trend kebutuhan bahan baku madu bulan Juli sampai dengan Desember 2018, menganalisis persediaan pengaman (safety stock) bahan baku madu, menganalisis titik pemesanan ulang (reorder point) bahan baku madu. Penelitian ini menggunakan metode deskriptif dengan metode pelaksanaan penelitian yaitu studi kasus. Metode analisis data yang digunakan adalah analisis model EOQ
\end{abstract}


(Economic Order Quantity), analisis regresi linier berganda, analisis trend, analisis safety stock dan analisis reorder point. Hasil penelitian menunjukkan bahwa pemesanan bahan baku madu yang optimal sebesar $6.524 \mathrm{~kg} /$ pesanan dengan frekuensi 17 kali pemesanan. Faktor biaya penyimpanan dan jumlah pemakaian mempengaruhi persediaan bahan baku sedangkan faktor biaya pemesanan dan waktu tunggu tidak mempengaruhi persediaan bahan baku di PT. Aksamala Adi Andana. Trend kebutuhan bahan baku madu di PT. Aksamala Adi Andana pada Bulan Juli sampai dengan Desember 2018 cenderung meningkat. Persediaan pengaman (safety stock) bahan baku madu yang harus tersedia di PT. Aksamala Adi Andana yaitu sebesar $766 \mathrm{~kg}$. Reorder point bahan baku madu di PT. Aksamala Adi Andana sebesar $2.915 \mathrm{~kg}$.

Kata kunci: economic order quantity, madu, safety stock, persediaan bahan baku, reorder point.

\section{PENDAHULUAN}

Indonesia mempunyai sumber daya alam lahan yang sangat luas untuk pengembangan industri madu. Madu merupakan salah satu produk hasil hutan bukan kayu yang menjadi produk unggulan di sektor kehutanan. Masyarakat mengenal madu sebagai produk yang mempunyai berbagai manfaat diantaranya untuk obat-obatan, produk kecantikan, anti toksin dan sebagai bahan baku dalam industri makanan maupun minuman.

Salah satu perusahaan yang menggunakan madu untuk bahan baku produksi adalah PT. Aksamala Adi Andana sebagai produsen madu untuk anak dengan merk dagang Vitabumin yang sudah memasarkan produknya hampir ke seluruh provinsi di Indonesia. Vitabumin menjadi pioneer madu yang diperkaya dengan ekstrak ikan gabus dan ekstrak temulawak. Hal ini menjadikan keunggulan tersendiri bagi produk vitabumin untuk dapat memenangkan persaingan pasar.

Produksi dapat dilakukan secara kontinyu diperlukan tersedianya bahan baku yang berkualitas dan mencukupi agar mesin-mesin dapat beroperasi secara efektif dan biaya yang dikeluarkan efisien. Pada saat musim hujan kualitas madu akan menurun dengan kadar air yang tinggi dan madu akan terasa masam. Jika madu tersebut memiliki kandungan air yang cukup tinggi akan memicu terjadinya fermentasi atau bergas. Menyimpan bahan baku dalam jumlah besar dapat menanggulangi kemungkinan terjadinya kehabisan persediaan tetapi persediaan 
yang besar dapat mengakibatkan besarnya pula biaya penyimpanan bahan baku tersebut.

Dalam persediaan, waktu tunggu mempengaruhi stok bahan baku yang ada pada perusahaan. Waktu tunggu diperhitungkan untuk menentukan waktu yang diperlukaan untuk pemesanan hingga persediaan bahan baku tiba di perusahaan. Harga bahan baku madu dipengaruhi dari kualitas madu yang akan dikirim dari para pemasok. Berdasarkan hal-hal tersebut, perusahaan harus mengetahui berapa jumlah kuantitas pemesanaan dan persediaan yang tepat agar biaya persediaan total menjadi ekonomis serta sesuai dengan jumlah permintaan yang ada. Metode EOQ dapat menentukan kuantitas pemesanan dan frekuensi pesanan optimal yang harus dilakukan perusahaan agar biaya total persediaan ekonomis.

Berdasarkan latar belakang yang telah diuraikan tersebut, penelitian ini bertujuan untuk (1) Menganalisis pemesanan bahan baku madu optimal di PT. Aksamala Adi Andana (2) Menganalisis pengaruh faktor-faktor biaya pemesanan, biaya penyimpanan, jumlah pemakaian dan waktu tunggu terhadap persediaan bahan baku madu di PT. Aksamala Adi Andana (3) Menganalisis trend pemakaian bahan baku madu di PT. Aksamala Adi Andana bulan Juli sampai dengan Desember 2018 (4) Menganalisis persediaan pengaman (safety stock) bahan baku madu di PT. Aksamala Adi Andana (5) Menganalisis titik pemesanan ulang (reorder point) bahan baku madu di PT. Aksamala Adi Andana.

\section{METODE PENELITIAN}

Penelitian ini menggunakan metode dasar penelitian metode deskriptif. Metode ini digunakan untuk memberikan penjelasan tentang bagaimana penerapan kebijakan PT. Aksamala Adi Andana untuk melakukan pengendalian bahan baku. Metode pelaksanaan penelitian ini menggunakan metode studi kasus. Penelitian ini dilakukan pada PT. Aksamala Adi Andana yang berlokasi di Jalan Aksamala 1 RT 3 Dukuh Petung, Bangunjiwo, Kasihan, Bantul Regency, Special Region of Yogyakarta. Perusahaan ini memproduksi vitamin madu dengan merk dagang vitabumin. Bahan baku madu yang digunakan merupakan madu jenis madu multiflora. Madu jenis ini didapatkan dari nektar yang berasal dari berbagai 
jenis flora sehingga perlu perlakuan khusus untuk mendapatkan bahan baku sesuai dengan kriteria perusahaan. Perusahaan ini juga menjadi pelopor penggunaan albumin dari ekstrak ikan gabus. Ikan gabus sangat kaya akan albumin yang menjadi sumber protein bagi tubuh anak.

\section{Pemesanan bahan baku madu optimal di PT. Aksamala Adi Andana}

Analisis tingkat pemesanan dari pemesanan bahan baku yang optimal dilakukan dengan menggunakan Economic Order Quantity (EOQ) pada setiap kali pemesanan

Adapun umus menghitung EOQ adalah sebagai berikut:

$$
Q^{*}=\sqrt{\frac{2 D S}{H}}
$$

Keterangan:

$Q^{*}=$ Jumlah pemesanan optimal bahan baku madu $(\mathrm{kg})$

$D$ = Kuantitas Penggunaan madu $(\mathrm{kg})$

$S=$ Biaya Pemesanan madu (Rp/ 2 minggu)

$H=$ Biaya penyimpanan per unit $(\mathrm{Rp} / \mathrm{kg})$

Untuk menguji hipotesis pertama, diduga persediaan bahan baku madu belum ekonomis.

$$
\begin{aligned}
& \mathrm{t}_{\text {hitung }}=\frac{\overline{Q r u l}-E O Q}{S D / \sqrt{n}} \\
& \mathrm{Sd}=\sqrt{\frac{\sum(Q \text { riil }-E O Q)^{2}}{n-1}}
\end{aligned}
$$

Keterangan:

EOQ = Jumlah pemesanan optimal bahan baku madu

$\mathrm{Q} \quad=$ Jumlah pemesana bahan baku madu riil

$\mathrm{Sd}=$ Standar Deviasi

$\mathrm{n} \quad=$ Banyaknya data

Kriteria Pengujian: 
Putri et.al. / Jurnal Dinamika Sosial Ekonomi Vol.20 No.1, Juni 2019

a. Jika $t_{\text {hitung }}>\mathrm{t}$ tabel maka Ha diterima, berarti persediaan bahan bahan baku madu belum optimal.

b. Jika $t$ hitung $\leq \mathrm{t}$ tabel maka Ho diterima, berarti persediaan bahan bahan baku madu sudah optimal

Pengaruh Faktor-Faktor Biaya Pemesanan, Biaya Penyimpanan, Jumlah Pemakaian dan Waktu Tunggu Terhadap Persediaan Bahan Baku Madu Di PT. Aksamala Adi Andana

Pada penelitian ini digunakan metode analisis regresi linier berganda (multiple linear regression) untuk mengetahui besarnya pengaruh faktor-faktor biaya pemesanan, biaya penyimpanan, harga bahan baku dan waktu tunggu terhadap persediaan bahan baku madu. Persamaan linear untuk analisis regresi linier berganda yaitu sebagai berikut (Subagyo dan Djarwanto Ps, 2005) :

$$
Y=a+b_{1} X_{1}+b_{2} X_{2}+\ldots \ldots+b_{k} X_{k}
$$

Keterangan:

$\mathrm{Y}=$ variabel terikat (persediaan bahan baku madu) $(\mathrm{kg} / 2 \mathrm{minggu})$

$\mathrm{a}=$ konstanta

$\mathrm{b}_{1}=$ koefisien regresi biaya pemesanan

$\mathrm{b}_{2}=$ koefisien regresi biaya penyimpanan

$\mathrm{b}_{3}=$ koefisien regresi harga bahan baku

$\mathrm{b}_{4}=$ koefisien regresi waktu tunggu

$\mathrm{X}_{1}=$ biaya pemesanan $(\mathrm{Rp} / 2$ minggu $)$

$\mathrm{X}_{2}=$ biaya penyimpanan $(\mathrm{Rp} / \mathrm{kg})$

$\mathrm{X}_{3}=$ jumlah pemakaian $(\mathrm{kg})$

$\mathrm{X}_{4}=$ waktu tunggu (hari)

e $=$ kesalahan (error term),

Trend Pemakaian Bahan Baku Madu Di PT. Aksamala Adi Andana Bulan Juli-Desember 2018

Analisis trend persediaan bahan baku untuk menghitung kebutuhan bahan baku madu ditahun mendatang, diduga trend persediaan bahan baku madu untuk 5 
bulan mendatang (Bulan Januari hingga Bulan Mei) pada tahun 2019 akan meningkat. Dapat diuji dengan menggunakan beberapa model rumus trend sebagai berikut :

a. Trend Linear memiliki model sebagai berikut:

$$
\mathrm{Yt}=\beta_{0}+\beta_{1} \mathrm{~T}
$$

Keterangan :

$\mathrm{Yt}=$ nilai data pada tahun $\mathrm{t}$

$\beta_{0}=$ konstanta, yang menunjukkan nilai data pada tahun awal

$\beta_{1}=$ besarnya perubahan data dari satu periode ke periode lainnya

$\mathrm{T}=$ tahun

b. Trend Kuadratik memiliki model sebagai berikut:

$$
\mathrm{Yt}=\beta_{0}+\beta_{1} \mathrm{~T}+\beta_{2} \mathrm{~T}^{2}
$$

c. Trend Pertumbuhan memiliki model sebagai berikut:

$$
\mathrm{Y}=\beta_{0} \mathrm{e}^{\beta_{1} \mathrm{~T}} \text { atau } \ln (\mathrm{Y})=\ln \beta_{0}+\beta_{1} \mathrm{~T}
$$

Keterangan : e adalah bilangan $=2,71766$

d. Trend kurva $\mathrm{S}$ memiliki model sebagai berikut:

$$
\mathrm{Yt}=\mathrm{e}^{(\beta 0+(\beta 1 / \mathrm{T}))} \text { atau } \ln (\mathrm{Y})=\beta_{0}+\left(\beta_{1} / \mathrm{T}\right)
$$

Persediaan Pengaman (Safety Stock) Bahan Baku Madu Di PT. Aksamala Adi Andana

Safety Stock menghitung persediaan pengaman atau safety stock menurut Ahyari (1986) dapat menggunakan rumus sebagai berikut:

Safety stock $=$ Jumlah standar deviasi dari tingkat kebutuhan $\mathrm{x} 1,65$

$S D=\sqrt{\frac{\sum(X-X)^{2}}{n}}$

Keterangan:

$\mathrm{SD}=$ Standar deviasi

$\underline{\mathrm{X}}=$ Pemakaian sesungguhnya

$X=$ Rata-rata pemakaian

$\mathrm{n}$ = Jumlah atau banyak data 
Putri et.al. / Jurnal Dinamika Sosial Ekonomi Vol.20 No.1, Juni 2019

Titik Pemesanan Ulang (Reorder Point) Bahan Baku Madu Di PT. Aksamala Adi Andana

Analisis reorder point digunakan untuk menganalisis titik pemesanan ulang menurut Heizer dan Render (2015) dapat digunakan rumus sebagai berikut:

$\mathrm{ROP}=$ Permintaan per hari $\mathrm{x}$ Waktu tunggu pesanan baru dalam hari $=(\mathrm{d} x \mathrm{~L})+$ Safety stock

Keterangan:

$\mathrm{d}=$ Kebutuhan bahan baku per hari

$\mathrm{L}=$ Waktu tunggu dalam hari atau minggu

Ss $=$ Persediaan pengaman $(\mathrm{kg} / 2$ minggu $)$

Untuk perhitungan kesalahan peramalan terdapat tiga dari perhitugan yang paling terkenal :

Rataan Deviasi Mutlak (Mean Absolute Deviation)

$M A D=\frac{\sum \mid \text { aktual }- \text { peramalan } \mid}{n}$

Rataan Kesalahan Kuadrat (Mean Squared Error)

$M S E=\frac{\sum \mid \text { Kesalahan peramalan }^{2} \mid}{n}$

Rataan Kesalahan Persen Mutlak (Mean Absolute Percent Error)

MAPE $=\frac{\sum_{i-I}^{n} 100 l_{\text {Aktwal }(i)}-\text { Aktwal (i) / Aktwal (i) }}{n}$

\section{HASIL DAN PEMBAHASAN}

\section{Pemesanan bahan baku madu optimal di PT. Aksamala Adi Andana}

Persediaan bahan baku terdiri dari penjumlahan persediaan awal dengan pemesanan.. Economic Order Quantity digunakan untuk menentukan volume atau jumlah pemesanan madu yang optimal untuk dilaksanakan pada setiap kali pemesanan oleh PT. Aksamala Adi Andana. Menurut penelitian Novijanto (2010) bahwa penggunaan metode EOQ dapat menghemat biaya yang dikeluarkan. Selain itu metode EOQ juga lebih efisien dibandingkan cara perhitungan 
tradisional (Prihasdi dan Rahardjo, 2012), karena penerapannya dapat membuat total biaya menjadi minimum (Djunaidi, et.al., 2005). Besarnya Economic Order Quantity (EOQ) di PT. Aksamala Adi Andana pada tahun 2017 dapat dilihat pada Tabel 1. berikut :

Tabel 1. Rata-rata Nilai Economic Order Quantity (EOQ) pada PT. Aksamala Adi Andana per Periode

\begin{tabular}{lr}
\hline \multicolumn{1}{c}{ Uraian } & Nilai \\
\hline Permintaan (kg) (D) & 4.957 \\
Biaya Pemesanan (Rp) (S) & 2.233 .440 \\
Biaya Penyimpanan (Rp/kg) (H) & 520 \\
Pemesanan Optimal (EOQ) (kg) & 6.524 \\
\hline
\end{tabular}

Sumber : Data Sekunder (diolah), 2018

Berdasarkan hasil analisis diketahui bahwa rata-rata jumlah pemesanan bahan baku optimal (EOQ) per pesanan dari Bulan Januari - Desember 2017 sebesar $6.524 \mathrm{~kg}$, sedangkan rata-rata pemesanan rill yang ada di PT. Aksamala Adi Andana sebesar $5.000 \mathrm{~kg}$. Berdasarkan hasil tersebut dapat disimpulkan bahwa pemesanan bahan baku madu yang dipesan oleh PT. Aksamala Adi Andana pada tahun 2017 tidak optimal, dikarenakan jumlah pemesanan rill lebih kecil dibandingkan dengan jumlah pemesanan optimal. Hal ini dikarenakan perusahaan menentukan jumlah pemesanan yang sedikit dengan frekuensi pemesanan yang sering. Frekuensi pemesanan merupakan salah satu cara yang digunakan untuk menghitung berapa kali pemesanan yang dilakukan dalam satu tahunnya. Frekuensi pemesanan yang optimal (EOQ) dapat dihitung dengan menggunakan rumus:

Tabel 2. Frekuensi Pemesanan Bahan Baku Madu PT. Aksamala Adi Andana per Periode.

\begin{tabular}{cccc}
\hline \multicolumn{2}{l}{ Kebijakan PT. Aksamala Adi Andana } & Metode Economic Order Quantity \\
& & \multicolumn{2}{c}{ (EOQ) } \\
\hline $\begin{array}{c}\text { Rata-rata Kuantitas } \\
\begin{array}{c}\text { Pemesanan } \\
(\mathrm{kg})\end{array}\end{array}$ & $\begin{array}{c}\text { Frekuensi } \\
\text { Pemesanan } \\
(\text { Kali })\end{array}$ & $\begin{array}{c}\text { Rata-rata Kuantitas } \\
\text { Pemesanan } \\
(\mathrm{kg})\end{array}$ & $\begin{array}{c}\text { Frekuensi } \\
\text { Pemesanan } \\
(\text { Kali })\end{array}$ \\
\hline 5,000 & 23 & 6,524 & 17 \\
\hline
\end{tabular}

Sumber : Data Sekunder (diolah), 2018 
Putri et.al. / Jurnal Dinamika Sosial Ekonomi Vol.20 No.1, Juni 2019

Berdasarkan Tabel 2 diketahui bahwa frekuensi pemesanan bahan baku madu di PT. Aksamala Adi Andana yang optimal (EOQ) yaitu sebanyak 17 kali, sedangkan frekuensi pemesanan bahan baku madu yang riil yaitu sebanyak 23 kali. Hasil tersebut menjelaskan bahwa frekuensi pemesanan yang dilakukan oleh PT. Aksamala Adi Andana pada tahun 2017 lebih banyak dari perhitungan optimal.

\section{Biaya Pemesanan Bahan Baku}

Biaya pemesanan bahan baku madu adalah biaya yang dikeluarkan oleh perusahaan dalam proses pemesanan bahan baku madu. Biaya pemesanan yang dikeluarkan oleh PT. Aksamala Adi Andana dapat dilihat pada Tabel 3.

Tabel 3. Rata-rata Biaya Pemesanan Bahan Baku PT. Aksamala Adi Andana per Periode

\begin{tabular}{lr}
\hline \multicolumn{1}{c}{ Uraian } & \multicolumn{2}{c}{ Nilai } \\
& $(\mathrm{Rp} / 2$ minggu $)$ \\
\hline Biaya Telepon & 24.435 \\
Biaya Transportasi & 2.000 .000 \\
Biaya Pembongkaran & 200.000 \\
Biaya Pencatatan & 9.005 \\
\hline Biaya Pemesanan & 2.233 .440 \\
\hline Sumber : Data Sekund
\end{tabular}

Sumber : Data Sekunder (diolah), 2019

Berdasarkan Tabel 3 diketahui rata-rata biaya pemesanan bahan baku madu yang dikeluarkan PT. Aksamala Adi Andana sebesar Rp 2.233.440 per pesanan. Besarnya rata-rata biaya telfon sebesar Rp 24.435 per pesanan, rata-rata biaya transportasi sebesar Rp 2.000.000 per pesanan, rata-rata biaya bongkar muat sebesar Rp 200.000 per pesanan, dan rata-rata biaya pencatatan sebesar Rp 9.005 per pesanan.

Biaya Penyimpanan Bahan Baku

Biaya penyimpanan adalah biaya yang dibutuhkan selama proses penyimpanan bahan baku madu di gudang. Biaya penyimpanan yang dibutuhkan oleh PT. Aksamala Adi Andana dapat dilihat pada Tabel 4. 
Tabel 4. Rata-rata Biaya Penyimpanan Bahan Baku PT. Aksamala Adi Andana per Periode

\begin{tabular}{|c|c|}
\hline Uraian & Nilai \\
\hline Biaya Tenaga Kerja (Rp) & 1.465 .837 \\
\hline Biaya Listrik (Rp) & 120.588 \\
\hline Biaya modal (Rp) & 1.864 .688 \\
\hline Total Biaya Penyimpanan $(\mathrm{Rp})$ & 3.451 .112 \\
\hline Persediaan $(\mathrm{kg})$ & 6.130 \\
\hline Biaya Penyimpanan per Unit (Rp/kg) & 520 \\
\hline
\end{tabular}

Sumber : Data Sekunder (diolah), 2018

Berdasarkan Tabel 4 dapat diketahui bahwa rata-rata biaya penyimpanan bahan baku madu sebesar Rp 520. Besar rata-rata biaya untuk 2 orang tenaga kerja gudang sebesar Rp 1.465.837., rata-rata biaya listrik yang dikeluarkan sebesar Rp 120.588., dan besarnya rata-rata biaya modal adalah $\mathrm{Rp} 1.864,688$. Dengan rata-rata jumlah persediaan sebesar $6,130 \mathrm{~kg}$ maka diperoleh total biaya penyimpanan per unit sebesar Rp 520.

Pengaruh Faktor-Faktor Biaya Pemesanan, Biaya Penyimpanan, Jumlah Pemakaian dan Waktu Tunggu Terhadap Persediaan Bahan Baku Madu Di PT. Aksamala Adi Andana

Besarnya jumlah persediaan bahan baku madu di PT. Aksamala Adi Andana dipengaruhi oleh beberapa faktor, yaitu jumlah pemakaian bahan baku, biaya pemesanan, biaya penyimpanan, dan waktu tunggu (lead time). Faktorfaktor tersebut mempengaruhi nilai persediaan bahan baku madu di PT. Aksamala Adi Andana, data tersebut dapat dilihat pada tabel berikut.

Tabel 5. Rata-rata Nilai Faktor-Faktor yang Mempengaruhi Persediaan Bahan Baku Madu di PT. Aksamala Adi Andana

\begin{tabular}{lr}
\hline \multicolumn{1}{c}{ Uraian } & Nilai \\
\hline Biaya Pemesanan $(\mathrm{Rp} / 2$ minggu) & 2.233 .440 \\
Biaya Penyimpanan $(\mathrm{Rp} / \mathrm{kg})$ & 520 \\
Jumlah pemakaian $(\mathrm{kg})$ & 4.957 \\
Waktu tunggu (hari) & 5 \\
\hline
\end{tabular}

Sumber : Data Sekunder (diolah), 2018 
Berdasarkan hasil analisis diketahui bahwa variabel biaya pemesanan, biaya penyimpanan, jumlah pemakaian, dan lead time mempengaruhi persediaan bahan baku madu di PT. Aksamala Adi Andana. Namun secara parsial hanya variabel jumlah pemakaian, dan biaya penyimpanan yang berpengaruh terhadap persediaan bahan baku madu di PT. Aksamala Adi Andana.

Variabel biaya pemesanan diketahui setelah dilakukan analisis tidak mempengaruhi persediaan bahan baku hal ini dikarenakan selama melakukan pemesanan perusahaan selalu memesan bahan baku dengan jumlah pemesanan yang relatif sama karena sudah adanya kontrak antara perusahaan dengan supplier. Sedangkan untuk variabel biaya penyimpanan diketahui bahwa biaya penyimpanan berpengaruh terhadap persediaan bahan baku madu. Jika biaya penyimpanan naik maka persediaan bahan baku madu juga akan naik, begitu juga sebaliknya. Variabel jumlah pemakaian diketahui bahwa jumlah pemakaian berpengaruh terhadap persediaan bahan baku madu. Hal ini dikarenakan jika perusahaan ingin melakukan produksi vitabumin dalam jumlah yang besar maka perusahaan membutuhkan bahan baku dengan jumlah yang besar, begitu juga sebaliknya. Waktu tunggu secara parsial tidak berpengaruh terhadap persediaan bahan baku madu sehingga variasi perubahan waktu tunggu tidak mempengaruhi persediaan bahan baku madu, hal ini dikarenakan variasi dari waktu tunggu tidak terlalu signifikan.

Trend Pemakaian Bahan Baku Madu Di PT. Aksamala Adi Andana Bulan Juli-Desember 2018

Trend dapat dilihat dari kecenderungan pola atau hubungan suatu keadaan yang akan datang dari keadaan yang sebelumnya.

Tabel 6. Perbandingan MAPE, MAD, MSD pada Metode Trend

\begin{tabular}{lrrrr}
\hline \multicolumn{1}{c}{ Ukuran } & \multicolumn{2}{c}{ Linier } & Kuadratik & $\begin{array}{r}\text { Pertumbuhan } \\
\text { Eksponensial }\end{array}$ \\
\hline MAPE & 11 & 11 & 11 & 12 \\
MAD & 446 & 447 & 447 & 502 \\
MSD & 427555 & 423893 & 430287 & 455671 \\
\hline
\end{tabular}

Sumber : Data Sekunder (diolah), 2018 
Menetapkan model yang akan digunakan dalam peramalan, dipilih model dengan nilai MAPE, MAD atau MSD yang paling kecil. Berdasarkan hasil tersebut dapat dikatakan bahwa nilai MAPE, MAD, dan MSD yang paling kecil adalah model kuadratik yang digunakan untuk melakukan analisis trend.

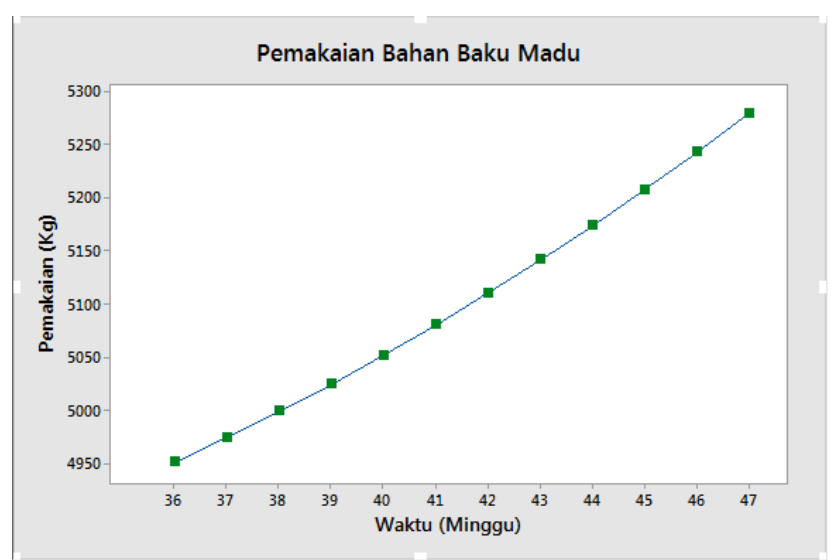

Gambar 1. Pemakaian bahan baku madu bulan Juli - Desember 2018

Berdasarkan Gambar 1 grafik proyeksi trend dengan model trend kuadratik, diketahui persamaannya yaitu $\mathrm{Yt}=5001-25,3 \mathrm{t}+0,66 \mathrm{t}^{2}$. Persamaan yang diperoleh tersebut digunakan untuk menghitung pemakaian bahan baku madu pada Bulan Juli sampai dengan Bulan Desember 2018. Berikut hasil perhitungan dan grafik trend yang diperoleh dari persamaan trend dengan model kuadratik:

Tabel 7. Perkiraan pemakaian bahan baku madu PT. Aksamala Adi Andana

\begin{tabular}{llcc}
\hline Tahun & Bulan & Minggu & Pemakaian Bahan Baku \\
\hline 2018 & Juli & 36 & 4.951 \\
& & 37 & 4.974 \\
& Agustus & 38 & 4.998 \\
& & 39 & 5.024 \\
& September & 40 & 5.051 \\
& & 41 & 5.080 \\
& Oktober & 42 & 5.110 \\
& & 43 & 5.141 \\
& November & 44 & 5.173 \\
& & 45 & 5.207 \\
& Desember & 46 & 5.242 \\
& & 47 & 5.279 \\
\hline
\end{tabular}

Sumber : Data Sekunder (diolah), 2018 
Berdasarkan hasil perhitungan dapat dilihat trend persediaan bahan baku yang akan dibutuhkan oleh PT. Aksamala Adi Andana akan meningkat pada setiap bulanya dimulai dari pemakaian bulan juli sebesar $4.946 \mathrm{Kg}$ hingga meningkat pada akhir bulan Desember sebesar 5.270 Kg.

Persediaan Pengaman (Safety Stock) Bahan Baku Madu Di PT. Aksamala Adi Andana

Persediaan yang dilakukan untuk melindungi atau menjaga kemungkinan terjadinya kekurangan bahan / barang (Herjanto, 1999 cit. Kushartini dan Almahdy, 2016). Dalam penelitian ini persediaan pengaman merupakan sejumlah persediaan bahan baku madu cadangan yang dimiliki oleh PT. Aksamala Adi Andana untuk mencegah terjadinya kehabisan stok bahan baku. Untuk menghitung besarnya safety stock yang dibutuhkan oleh PT. Aksamala Adi Andana adalah dengan menggunakan rumus pada tabel 8. Berdasarkan hasil perhitungan, dapat dikatakan safety stock yang harus ada di PT. Aksamala Adi Andana sebesar $766 \mathrm{Kg}$.

Tabel 8. Perhitungan nilai safety stock pada PT. Aksamala Adi Andana per periode

\begin{tabular}{lc}
\hline \multicolumn{1}{c}{ Uraian } & Nilai \\
\hline Standar Deviasi & 501,50 \\
$\mathrm{Z}$ & 1,65 \\
\hline Safety Stock $=$ SD x Z & 766,00 \\
\hline
\end{tabular}

Sumber : Data Sekunder (diolah), 2018

Titik Pemesanan Ulang (Reorder Point) Bahan Baku Madu Di PT. Aksamala Adi Andana

Perhitungan re-order point menurut kebijaksanaan perusahaan nilainya lebih kecil dibandingkan penghitungan dengan metode EOQ dikarenakan adanya perhitungan persediaan pengaman serta pemakaian saat waktu tunggu (Sarjono dan Kuncoro, 2014). Bahan baku madu digunakan setiap hari untuk proses produksi, Pemesanan madu dilakukan apabila stok bahan baku digudang sudah berkurang dalam jumlah yang tertentu. 
Tabel 9. Perhitungan tingkat pemesanan ulang bahan baku madu di PT. Aksamala Adi Andana per periode

\begin{tabular}{lr}
\hline \multicolumn{1}{c}{ Uraian } & Nilai \\
\hline Permintaan per hari (d) (kg/hari) & 404 \\
Waktu tunggu/lead time (L) & 5 \\
Safety stock & 766 \\
\hline Reorder Point $(\mathrm{ROP})=\mathrm{d} \times \mathrm{L}$ & 2.915 \\
\hline Safety Stock $=$ SD x Z & 766 \\
\hline
\end{tabular}

Sumber : Data Sekunder (diolah), 2018

Berdasarkan Tabel 9 dapat diketahui kebutuhan rata-rata madu setiap bulannya sebesar $4.957 \mathrm{~kg} / 2$ minggu dan untuk waktu tunggu pemesanan (lead time) selama 4-6 hari untuk bahan baku sampai di gudang bergantung kondisi dari supplier. Berdasarkan hasil perhitungan didapatkan hasil rata-rata reorder point untuk setiap pemesanan adalah sebesar $2.915 \mathrm{~kg}$.

Persediaan $(\mathrm{kg})$

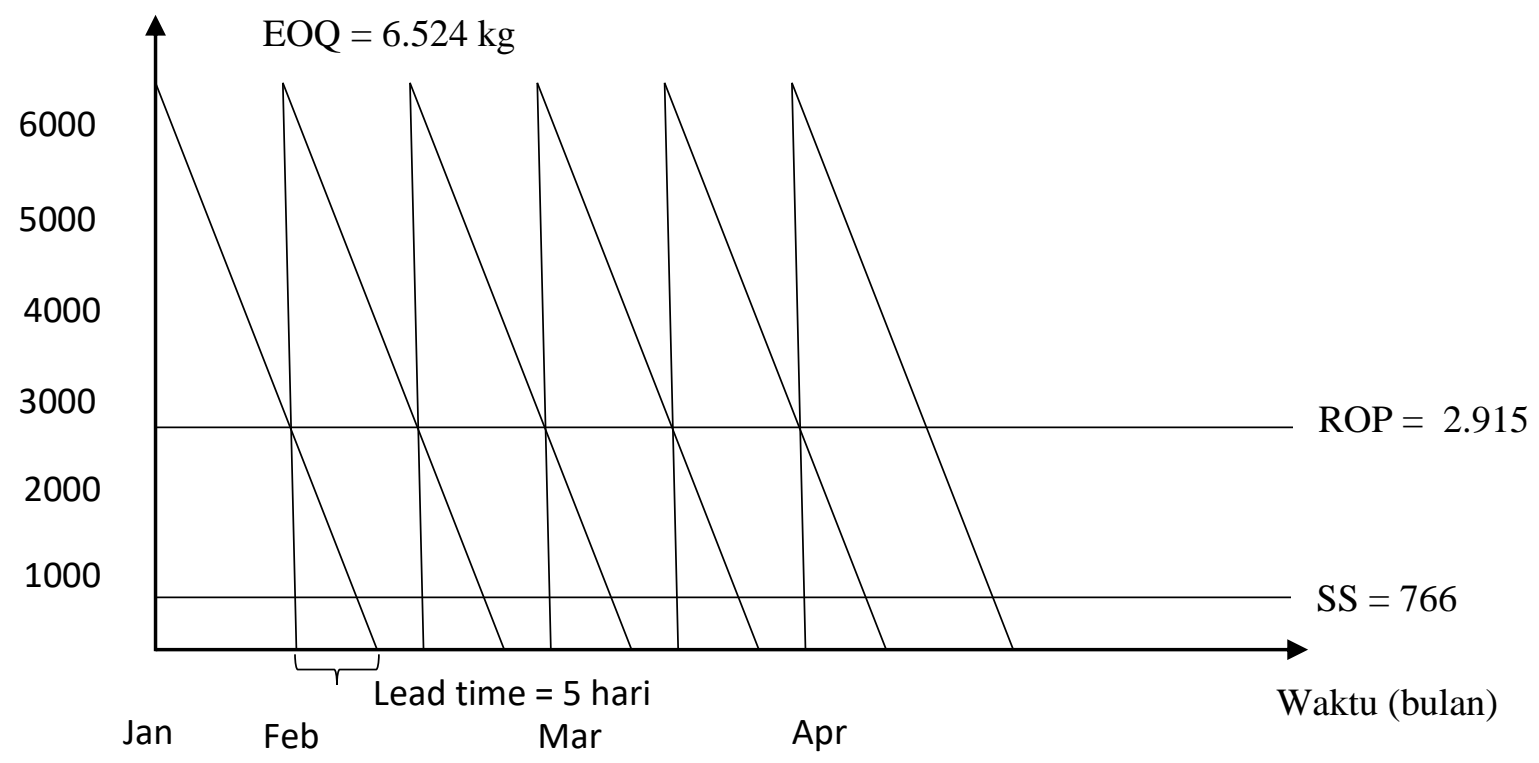

Gambar 2. Reorder Point

Berdasarkan Gambar 2 dapat diketahui bahwa jumlah pemesanan bahan baku optimal adalah $6.524 \mathrm{~kg}$ dengan tingkat pemesanan ulang (ROP) sebesar $2.915 \mathrm{~kg}$, safety stock sebesar $766 \mathrm{~kg}$ dan waktu tunggu selama 5 hari. 


\section{KESIMPULAN DAN SARAN}

\section{Kesimpulan}

Pemesanan bahan baku madu yang optimal di PT. Aksamala Adi Andana adalah sebesar $6.524 \mathrm{~kg} /$ pesanan dengan frekuensi 17 kali pemesanan. Faktor biaya penyimpanan dan jumlah pemakaian mempengaruhi persediaan bahan baku sedangkan faktor biaya pemesanan dan waktu tunggu tidak mempengaruhi persediaan bahan baku di PT. Aksamala Adi Andana. Trend pemakaian bahan baku madu di PT. Aksmala Adi Andana untuk bulan Juli hingga Desember 2018 cenderung meningkat. Safety stock atau persediaan pengaman bahan baku madu yang dibutuhkan oleh PT. Aksamala Adi Andana sebesar 766 kg. Reorder Point (ROP) atau titik pemesanan kembali bahan baku madu pada PT. Aksamala Adi Andana sebesar $2.915 \mathrm{~kg}$.

\section{Saran}

PT. Aksamala Adi Andana sebaiknya dapat menerapkan metode EOQ sebagai cara untuk melakukan pemesanan bahan baku madu dengan menambah jumlah pemesanan dan menurunkan frekuensi pemesanan. PT. Aksamala Adi Andana dapat mengkaji ulang tingkat reorder point dan menerapkan safety stock dikarenakan tingkat reorder point sebesar $2000 \mathrm{~kg} / \mathrm{bulan}$ dan belum menerapkan safety stock sedangkan safety stock yang dibutuhkan perusahaan adalah $766 \mathrm{~kg}$ dan reorder point sebesar $2.915 \mathrm{~kg}$. Sehingga diharapkan nantinya proses produksi di perusahaan dapat berjalan dengan lancar dan tidak terhambat.

\section{DAFTAR PUSTAKA}

Ahyari, Agus. 1986. Manajemen Produksi Pengendalian Produksi Buku I. Yogyakarta: BPFE Yogyakarta.

Djunaidi M., Nandiroh S., dan Marzuki I.O. 2005.Pengaruh Perencanaan Pembelian Bahan Baku dengan Model EOQ untuk Multiitem dengan All Unit Discount. Jurnal Ilmiah Teknik Industri, 4 (2) : 86-94.

Heizer, Jay dan Render B.. 2015. Manajemen Operasi. Edisi 11. Jakarta: Salmeba Empat.

Kushartini D. dan Almahdy I. 2016. Sistem Persediaan Bahan Baku Produk Dispersant Di Industri Kimia. Jurnal PASTI 10 (2) : 217 - 234. 
Novijanto, Noer. 2010. Penentuan Jumlah Persediaan Bahan Baku Produk Tempe Dengan Metode Economic Order Quantity. Jurnal Agroteknologi 4 (1) : 35-40.

Prihasdi R.D. dan Rahardjo, S.N. . 2012. Efisiensi Metode Economical Order Quantity (EOQ) Dalam Pengambilan Keputusan Pembelian Bahan Baku dan Pengaruhnya Terhadap Total Biaya Pembelian Pada PT Amitex (Amanah Mitra Industri) Buaran Kabupaten Pekalongan. Diponegoro Journal of Accounting, 1 (1) : 1-12.

Sarjono H. dan Kuncoro E.A. 2014. Analisis Perbandingan Perhitungan Re-Order Point. Binus Business Review 5 (1) : 288-300.

Subagyo, P. dan Djarwanto PS. 2005. Statistik Induktif. Edisi Kelima. Yogyakarta : BPFE. 